Atıfta Bulunmak İçin / Cite This Paper: Çeştepe, H. ve Zorlu, S. (2019). "Comparative Analysis of Competitiveness of Shangai Cooperation Organization Members and Turkey", Manas Sosyal Araştırmalar Dergisi, 8(3): 2559-2578.

Araștırma Makalesi

\title{
COMPARATIVE ANALYSIS OF COMPETITIVENESS OF SHANGAI COOPERATION ORGANIZATION MEMBERS AND TURKEY ${ }^{1}$
}

\author{
Hamza ÇEŞTEPE \\ Zonguldak Bulent Ecevit University, Faculty of Economics and Administrative Sciences \\ hamzac@hotmail.com \\ ORCID ID: 0000-0003-1541-5703
}

Selcen ZORLU

Zonguldak Bulent Ecevit University, Maritime Faculty

selcenzorlu@gmail.com

ORCID ID: 0000-0002-9508-8521

\begin{abstract}
The Shanghai Cooperation Organization (SCO) is a regional integration that emerged in the Central Asian region about 20 years ago and has been on the agenda of Turkey for the last few years. In particular, disputes between Turkey and EU in recent years have led the some people to express the SCO as an alternative to the EU in the future. In this study, the export specialization and competitiveness of the SCO members and Turkey are analysed in terms of products and Lall (2000) based technological categories. The comparative advantages of the SCO countries and Turkey are calculated using the Balassa index for the 1993-2016 period. Analysis revealed that Turkey has a comparative advantage in especially low and medium technology and resource based products. It is evident that while the Russian Federation, Kazakhstan and Kyrgyzstan have comparative advantage in primary and resource-based products, China in low and medium technology products, India in primary, resource-based and low-tech products and Pakistan in low technology and primary products. In other words Turkey and SCO countries possess a similar comparative advantage pattern with respect to the technological classification. Besides, both Turkey and SCO countries has revealed comparative disadvantage in high-tech products. Additionally, in the case of products in which Turkey has a strong comparative advantage, it is shown that the closest competitors are China, India and Pakistan.
\end{abstract}

Keywords: Competitiveness, Revealed Comparative Advantage, Balassa Index, Shanghai Cooperation Organization, Turkey

\section{ŞANGHAY İSBBIRLIĞİ ÖRGÜTÜ ÜYELERI VE TÜRKIYY'NINN KARȘILASTTIRMALI REKABET GÜCÜ ANALIZİ}

Öz

Şanghay İșbirliği Örgütü (ȘïÖ) yaklașık 20 yıl önce Orta Asya bölgesinde ortaya çıkan ve son birkaç y1ldır Türkiye'nin de gündeminde yer almaya başlayan bir bölgesel entegrasyon oluşumudur. Özellikle son dönemlerde Türkiye-AB ilișkilerinde yașanan bazı sıkıntılar, çeșitli kesimler tarafından Şiö'nün Türkiye için AB'ye ileride olası bir alternatif anlamında dillendirilmesine yol açmıştır. Bu çalışmada ŞiÖ bölgesi ülkeleriyle Türkiye'nin ihracat uzmanlaşma ve rekabet düzeyleri ürün ve Lall (2000) tabanlı teknolojik kategoriler açısından

\footnotetext{
${ }^{1}$ This paper is presented as a summary in International Conference of Management Economics and Business (ICMEB'17) held on 7-9 September 2017 in Zonguldak
} 
karşılaştırmalı olarak analiz edilmiştir. Çalışmada 1993-2015 yılları arasında ŞïÖ ülkeleri ve Türkiye'nin açıklanmış karşılaştırmalı üstünlükleri Balassa endeksiyle hesaplanmıştır. Yapılan analizlerde, Türkiye'nin karşılaştırmalı üstünlüğünün özellikle düşük ve orta teknoloji ürünlerle kaynak tabanlı ürünlerde olduğu görülmüştür. ŞïÖ üyelerine bakıldığında ise Rusya Federasyonu, Kazakistan, Kırgızistan’ın birincil ve kaynak tabanlı ürünlerde karşılaştırmalı üstünlüğge sahip iken; Çin'in düşük ve orta teknolojili ürünlerde, Hindistan'ın birincil, kaynak tabanlı ve düşük teknolojili ürünlerde, Pakistan'ın ise düşük teknolojili ile birincil ürünlerde karşılaştırmalı üstünlüğünün olduğu tespit edilmiştir. Başka bir ifadeyle, Türkiye ve ŞİÖ ülkeleri teknolojik sınıflandırma açısından benzer bir karşılaştırmalı üstünlük modeline sahiptir. İleri teknolojili ürünlerde ise incelenen ülkelerin karşılaştırmalı üstünlüğünün olmadığ belirlenmiştir. Buna ilaveten, Türkiye'nin güçlü karşılaştırmalı üstünlüğe sahip olduğu ürünlerde en yakın rakiplerinin Çin, Hindistan ve Pakistan olduğu görülmüştür.

Anahtar Kelimeler: Rekabet Gücü, Açıklanmış Karşılaştırmalı Üstünlük, Balassa Endeksi, Şanghay İşbirliği Örgütü, Türkiye

\section{INTRODUCTION}

The regionalization movements that first appeared in the world in the second half of the 19th century entered a period of rapid increase from the end of the 1980s, following a fluctuating course in later periods. This process, especially pioneered by the European Union, continues today and many developed and developing countries are actively involved in this process. Some of today's regional integration movements are relatively more regional unions, such as the customs union or free trade areas, while others are still co-operative. One of these co-operative movements is the Shanghai Cooperation Organization (SCO), which emerged in the Central Asian region about 20 years ago and has started to take place on the agenda of Turkey for the last few years.

There is no single reason why countries want to take part in a regional integration movement. These reasons, which are generally classified as economic and political vary from country to country and from region to region. Political reasons played a role in the establishment of European Union, and the economic reasons influenced the establishment of others such as EFTA and NAFTA. However, although political incentives may be the main reasons for establishing regional integration, economic factors have been determinant and the aim of developing extra-regional and intra-regional trade has become more prominent.

The purpose of this study is to analyse Turkey's competitiveness with the countries of the SCO, which is founded in the 1990s with security concerns and political reasons, but now attracting economic attention with the rapid economic development of some of the countries. This study would like to highlight similarities and differences of competitiveness between Turkey and SCO member countries.

Although there are some political and economic studies about Shanghai Cooperation Organization in the literature, there are no studies on the competitiveness of the countries in 
the region. With this study, it is aimed to fill this gap in the literature and to guide the works to be done afterwards.

Balassa's Revealed Comparative Advantage Index is calculated in the study using the Standard International Trade Classification Revision 3 (SITC Rev. 3) three-digit trade data and presented according to Lall's (2000) technological classification of export for Turkey and the SCO member countries. In addition, the commodities in which Turkey possess strong comparative advantage for 2015-2016 period are compared according to the RCA index averages of SCO member countries to determine Turkey's competitors and their market potential in the region.

The rest of this study is structured as follows: The economic and commercial structure of the SCO and Turkey are set out statistically in Section 2. In Section 3, the study briefly summarizes the empirical studies. The data, methodology and empirical findings of the study is discussed in Section 4 and 5. Competitiveness of Turkey and SCO countries are compared in Section 6. The final section of the study summarizes the main results.

\section{SHANGHAI COOPERATION ORGANIZATION MEMBERS' AND} TURKEY'S ECONOMIC AND COMMERCIAL STRUCTURE

The basis of the SCO is the platform called Shanghai Five, which is established in 1996 to solve border disputes and build border security between Russia, Kazakhstan, Kyrgyzstan and Tajikistan, neighbouring China. This formation is named SCO in 2001 with the participation of Uzbekistan. SCO, which is founded and managed only by Asian countries, is the first example of multilateral organizations independently developed by China (Grace, 2016: 1).

SCO, covering the Central Asian region except Turkmenistan and established entirely in line with China's initiative (Y1ldırım, 2007), has gone to a significant diversification in its member profile on 9 June 2017. During the summit held in Astana, South Asia's two major countries, Pakistan and India, are declared full-fledged members of the SCO. The SCO currently comprises with eight member states represents nearly half of the world population, as well as economic and geographic size. Other than eight member countries SCO has four observer states (Islamic Republic of Afghanistan, the Republic of Belarus, the Islamic Republic of Iran and the Republic of Mongolia) and six dialogue partners (the Republic of Azerbaijan, the Republic of Armenia, the Kingdom of Cambodia, the Federal Democratic Republic of Nepal, the Republic of Turkey, and the Democratic Socialist Republic of Sri Lanka). 
Furthermore, the SCO has established links with international organizations such as the United Nations, the European Union, the Association of Southeast Asian Nations (ASEAN) and the Organization for Islamic Cooperation.

The organization's main objectives are to strengthen mutual trust and neighbourhood among member states; developing effective cooperation in politics, economics, research, technology and culture together with education, energy, environmental protection and other fields; to participate in the efforts to secure and maintain peace, security and stability in the region and to ensure that it moves towards a democratic, just and rational international political and economic order. However, after the statements of the Russian President Putin in 2007, although not being articulated openly, it is stated that the purpose of the organization evolved into becoming a separate bloc against the western bloc led by the United States of America (Eğilmez, 2016).

In 2016, SCO ranks third in terms of production with a $\$ 12.712,5$ billion total GDP (excluding India and Pakistan) after the US and the European Union. If we include India and Pakistan in 2017, the region reaches a GDP of \$ 15.252, 9 billion. However, it should not be forgotten that the total population of this region is almost half of the world population. Region countries are generally included in the group of middle income countries in terms of income per capita. As shown in Table 1, China, Russia and India are economically stronger than other countries in the region. Turkey is in a better situation in terms of per capita income from all SCO countries, but inflation and unemployment is relatively high in Turkey.

Table 1. Basic Macro Economic Indicators of SCO Members and Turkey (2016)

\begin{tabular}{lcccccc}
\hline Country & $\begin{array}{c}\text { Per Capita } \\
\text { Income } \\
\text { (USD) }\end{array}$ & $\begin{array}{c}\text { Inflation } \\
(\boldsymbol{\%})\end{array}$ & $\begin{array}{c}\text { Unemployment } \\
\mathbf{( \% )}\end{array}$ & $\begin{array}{c}\text { Public } \\
\text { Debt } / \\
\text { GDP }(\boldsymbol{\%})\end{array}$ & $\begin{array}{c}\text { Export / } \\
\text { GDP }\end{array}$ & $\begin{array}{c}\text { Current } \\
\text { Account } \\
\text { Balance / } \\
\text { GDP }(\boldsymbol{\%})\end{array}$ \\
\hline China & 8.123 & 2.0 & 4.0 & 46.2 & 19.6 & 1.7 \\
\hline Russian Fed. & 8.748 & 7.0 & 5.5 & 17.0 & 25.7 & 1.7 \\
\hline Kazakhstan & 7.510 & 14.5 & 5.0 & 21.0 & 32.6 & -6.0 \\
\hline Kyrgyzstan & 1.077 & 3.9 & 7.4 & 58.4 & - & -9.3 \\
\hline Tajikistan & 795 & 5.9 & - & 35.3 & - & -5.0 \\
\hline Uzbekistan & 2.110 & 7.9 & - & 11.5 & 20.6 & 1.3 \\
\hline India & 1.709 & 4.8 & - & 69.5 & 19.2 & -0.9 \\
\hline Pakistan & 1.468 & 2.8 & 5.9 & 66.8 & 8.7 & -1.1 \\
\hline Turkey & 10.787 & 7.7 & 10.7 & 29.0 & 22.1 & -3.8 \\
\hline
\end{tabular}

Source: IMF (2017), World Economic Outlook, April 2017

http://www.imf.org/external/pubs/ft/weo/2017/01/weodata/weoselgr.aspx, 15.07.2017; The World Bank (2017), http://data.worldbank.org/indicator, 29.07.2017

In 2016 the foreign trade deficit of $\$ 42$ billion against the SCO member countries is $75 \%$ of Turkey's total foreign trade deficit. Turkey's share in total exports to the European Union (EU) member countries, which is Turkey's most important foreign trade partner, is 
$48 \%$, whereas the share of exports to members of the SCO is $4.6 \%$, the share of Turkey's total imports from the EU is $39 \%$, whilst the share of imports from the members of the SCO is $24.5 \%$. About $75 \%$ of the Turkey's total foreign trade deficit is due to members of the SCO and $16.3 \%$ of the trade deficit with the EU.

Table 2. Turkey's Foreign Trade with SCO, EU and World (2016, thousand USD)

\begin{tabular}{lrrr}
\hline Countries & \multicolumn{1}{c}{ Export } & \multicolumn{1}{c}{ Import } & Balance of Foreign Trade \\
\hline Russian Federation & $1,732,954$ & $15,162,386$ & $-13,429,432$ \\
\hline Kazakhstan & 623,715 & $1,093,897$ & $-470,182$ \\
\hline Uzbekistan & 533,018 & 709,292 & $-176,274$ \\
\hline Tajikistan & 151,621 & 162,255 & $-10,634$ \\
\hline Kyrgyzstan & 308,933 & 101,067 & 207,866 \\
\hline Pakistan & 346,896 & 263,354 & 83,542 \\
\hline India & 651,703 & $5,757,246$ & $-5,105,543$ \\
\hline China & $2,328,044$ & $25,441,433$ & $-23,113,389$ \\
\hline Total $(\mathbf{S C O})$ & $6,676,884$ & $48,690,930$ & $-42,014,046$ \\
\hline EU-28 & $\mathbf{6 8 , 3 4 3 , 9 0 8}$ & $77,501,203$ & $-9,157,295$ \\
\hline World & $\mathbf{1 4 2 , 5 2 9 , 5 8 4}$ & $\mathbf{1 9 8 , 6 1 8 , 2 3 5}$ & $\mathbf{- 5 6 , 0 8 8 , 6 5 1}$ \\
\hline
\end{tabular}

Source: Turkish Statistical Institute (2017), Main Statistics, http://www.tuik.gov.tr/UstMenu.do?metod=temelist, 29.07.2017

\section{EMPIRICAL LITERATURE SURVEY}

It seems that studies on the comparison of competitiveness of Turkey and the other countries or groups of countries are usually made in the case of European Union countries. Among these studies, for example, in the study of Şimşek, Seymen and Utkulu (2010), the competitiveness of Turkey's in the EU market has been analysed using 3-digit foreign trade data for 1993-2005 period. In addition to the various RCA indices, other supplementary and complementary measures of competitiveness are also used in the study. Şimşek, Seymen and Utkulu pointed out that Turkey has a comparative advantage in exporting raw materials and labour intensive products and has a relatively high advantage in capital intensive goods. The study also finds that there is no comparative advantage of Turkey in both easy and difficult to imitate goods.

No similar work is found on the SCO region. However, there are some studies on the Central Asian region. In Lord's (2015) study, RCA index is calculated by using Harmonized System Codes (HS Code) for 2010-2013 period. As a result of the analysis, the main findings for each of the eight countries are listed as well as the comparative advantages of these countries in seven major commodity categories. Lord pointed out that primary agricultural products have the highest average RCA among the countries in the Central and South Asia. This sector is followed by textile-footwear and minerals. On the contrary, none of the 
countries in the region have a comparative advantage in the wood and wood products sector.

A summary of the other studies related to competitiveness is given in Table 3:

Table 3. Selected Studies Related to Competitiveness

\begin{tabular}{|c|c|c|c|}
\hline Work & Content & Period & Conclusions \\
\hline $\begin{array}{l}\text { Şimşek, Şimşek, } \\
\text { Nurbayev (2017) }\end{array}$ & $\begin{array}{l}\text { Kazakhstan and } \\
\text { Eurasian Economic } \\
\text { Union Market }\end{array}$ & $1998-2014$ & $\begin{array}{l}\text { The competitiveness of Kazakhstan in the } \\
\text { Eurasian Economic Union market is } \\
\text { measured using different trade indices. It is } \\
\text { determined that Kazakhstan has a } \\
\text { comparative advantage in raw material } \\
\text { intensive products in the Eurasian Economic } \\
\text { Union Market and comparative disadvantage } \\
\text { in labour intensive products. }\end{array}$ \\
\hline Şahin (2016) & Turkey and China & $1992-2013$ & $\begin{array}{l}\text { It is found that Turkey's competitiveness in } \\
\text { exports is high in labour-intensive and } \\
\text { capital intensive goods, and that China has a } \\
\text { high RCA in labour intensive goods. } \\
\text { Moreover, China's competitiveness in the } \\
\text { exports of goods that are easy and difficult to } \\
\text { imitate started to increase. }\end{array}$ \\
\hline Çiçek and Bashimov (2016) & $\begin{array}{l}\text { Central } \\
\text { Countries }\end{array}$ & $2001-2012$ & $\begin{array}{l}\text { Central Asian countries except Kazakhstan } \\
\text { have a comparative advantage in cotton } \\
\text { trade, but in the last decade there has been a } \\
\text { decline in the RCA index of cotton and } \\
\text { cotton products of Central Asian countries. }\end{array}$ \\
\hline Raghuramapatruni (2015) & BRICS Countries & $2001-2014$ & $\begin{array}{l}\text { BRICS countries are complementary to each } \\
\text { other rather than being competitive in the } \\
\text { various sectors analysed in the study and the } \\
\text { countries have given higher potential for the } \\
\text { multilateral trading system. }\end{array}$ \\
\hline Taneja and Wani (2014) & India and China & $1995-2011$ & $\begin{array}{l}\text { The SITC 1-digit data is used to calculate the } \\
\text { RCA index of India and China as well as the } \\
\text { Revealed Export Dependence index. The } \\
\text { empirical results reveal that India and China } \\
\text { have comparative advantage in the } \\
\text { commodity groups such as raw materials, } \\
\text { tropical agricultural products, animal } \\
\text { products, cereals, capital intensive } \\
\text { manufacturing and chemical substances. }\end{array}$ \\
\hline Erkan (2012) & $\begin{array}{l}\text { BRIC Countries } \\
\text { and Turkey }\end{array}$ & & $\begin{array}{l}\text { It has been determined that BRIC economies } \\
\text { specialize exports of raw materials and } \\
\text { labour intensive products in general, whereas } \\
\text { Turkey specializes in exports of labour and } \\
\text { capital intensive products. }\end{array}$ \\
\hline $\begin{array}{l}\text { Kösekahyaoğlu } \\
\text { Özdamar (2011) }\end{array}$ & $\begin{array}{l}\text { Turkey, China and } \\
\text { India }\end{array}$ & 1990-2009 & $\begin{array}{l}\text { It is seen that the competitiveness of the } \\
\text { three countries is basically based on labour- } \\
\text { intensive goods as expected, but in recent } \\
\text { years the importance of especially capital- } \\
\text { intensive goods for India has increased even } \\
\text { more. }\end{array}$ \\
\hline $\begin{array}{l}\text { Shoufeng, Feng, and Zhang } \\
\text { (2011) }\end{array}$ & $\begin{array}{l}\text { China and Central } \\
\text { Asian Countries }\end{array}$ & $2002-2009$ & $\begin{array}{l}\text { China and Central Asia countries have } \\
\text { different superiorities, particularly in the } \\
\text { agricultural commodity categories, which } \\
\text { offer a wide bilateral trade potential on the } \\
\text { basis of comparative advantage. }\end{array}$ \\
\hline Şimşek and Sadat (2009) & $\begin{array}{l}\text { Turkey and ECO } \\
\text { Countries }\end{array}$ & $1997-2005$ & $\begin{array}{l}\text { Turkey has a revealed comparative } \\
\text { advantage, in labour intensive goods, } \\
\text { whereas it has revealed comparative } \\
\text { disadvantage in raw material intensive } \\
\text { goods. }\end{array}$ \\
\hline
\end{tabular}




\begin{tabular}{|c|c|c|c|}
\hline Work & Content & Period & Conclusions \\
\hline Veeramani (2008) & China and India & $1980-2003$ & $\begin{array}{l}\text { It has been found that China and India have } \\
\text { comparative advantage over labour-intensive } \\
\text { goods, their comparative advantages are low } \\
\text { in technology-intensive goods, but the } \\
\text { comparative advantage in technology- } \\
\text { intensive goods gradually increases in both } \\
\text { countries. }\end{array}$ \\
\hline Khatibi (2008) & $\begin{array}{l}\text { Kazakhstan and } \\
\text { AB-27 }\end{array}$ & $1999-2006$ & $\begin{array}{l}\text { Although Kazakhstan has competitiveness in } \\
\text { various sectors, such as energy and } \\
\text { manufacturing, it tends to decline in almost } \\
\text { all sectors. }\end{array}$ \\
\hline Tabata (2006) & Russian Federation & 1994-2005 & $\begin{array}{l}\text { It is noted that the comparative advantage in } \\
\text { oil and gas exports has increased and meat, } \\
\text { plastics and automobiles have decreased in } \\
\text { production and imports have increased in } \\
\text { these products. }\end{array}$ \\
\hline Kaya (2006) & $\begin{array}{l}\text { Turkey and AB- } \\
\text { 15/AB-10, Some } \\
\text { Candidate } \\
\text { Countries }\end{array}$ & $1991-2003$ & $\begin{array}{l}\text { As regards Turkey's export specialization } \\
\text { within the European Union, the } \\
\text { manufacturing industry has become more } \\
\text { specialized in the exports of labour-intensive } \\
\text { and non-technological investment-free } \\
\text { products. }\end{array}$ \\
\hline
\end{tabular}

\section{DATA SET DESCRIPTION AND METHODOLOGY}

The Standard International Trade Classification Revision 3 (SITC Rev. 3) 3-digit commodity group data for the period 1993-2016 has been downloaded from the UN Comtrade database. However, for Russian Federation this data set includes the 1996-2016 period, for Kazakhstan 1995-2016 period, for Kyrgyzstan 1995-2016 period except 1997 and 2014, and finally for Pakistan 1993-2016 except 1994.

For Tajikistan data set for only 2000 exists and there is no data from Uzbekistan. Consequently, Tajikistan and Uzbekistan are not included in the forthcoming analysis.

Since national data do not provide information on the technological development of countries according to years, it is necessary to use a technological classification. The commodity list (based on SITC Revision 3 (Lall, 2000) is used according to the technological categories listed on the https://unctadstat.unctad.org.

Accordingly, the products are classified as follows (Lall, 2000: 8-9):

1) Primary Products (PM): The products in this class do not need much analysis in terms of the technological basis of comparative advantage (e.g. fresh fruit, meat, rice, cocoa, tea, coffee, wood, coal, crude oil, gas).

2) Manufactured Products: Within export of these goods, technological categories and sub-categories are as follows:

- Resource Based Products (RB): The products in this class tend to be simple and labour-intensive (e.g. simple food or leather processing). There are segments using capital, 
scale and skill-incentive technologies like oil refining or modern processed foods. There are two subcategories:

○ Agriculture-based products (RB1): Prepared meats/fruit, beverages, wood products, vegetable oils etc.

O Other resource based products (RB2): Ore concentrates, petroleum/rubber products, cement, cut gems, glass etc.

- Low Technology Products (LT): This class primarily includes capital equipment. The lower limit of the class has relatively simple skill requirements. Many process products are not differentiated and compete on price. Therefore, labour costs become an important component of competitiveness. Scale economies and entry barriers are generally low. Subgroups;

○ Textile, garment and footwear cluster (LT1): Textile fabrics, clothing, leather and manufactures of leather, travel goods etc.

○ Other low technology products (LT2): Pottery, simple metal parts/structures, furniture, jewellery, toys, plastic products etc.

- Medium Technology Products (MT): They form the majority of skilful and scale intensive technologies in capital goods and intermediates, and are at the core of the industrial activities of mature economies. They tend to have complex technologies; R\&D levels are moderately high, requiring high skills and long training durations. Products in the engineering and automotive sub-sectors are sector-linked and significant interaction is required between companies to achieve the best result. Thus, the medium technology products (MT) are divided into three subgroups:

○ Automotive products (MT1): Motor vehicles for the transport of persons and goods, road motor vehicles etc.

○ Process industries (MT2): Synthetic fibres, chemicals and dyes, fertilizers, plastics, iron, pipes/tubes etc.

○ Engineering products (MT3): Agricultural machines, food-processing machines, metal working machinery and parts, optical goods etc.

While engineering products (MT3) focus on commodity design and development, the process industry (MT2) includes undifferentiated products and needs large scale installations.

- High-tech products (HT): They have advanced and fast changing technologies; high R\&D investments and commodity design are of primary importance. The most advanced technologies require advanced technological infrastructure and highly specialized technical 
skills. There is a close interaction between companies and between firms and universities or research institutions.

High technology products (HT) are divided into two subgroups:

○ Electronics and electrical products (HT1): Office/data processing/telecommunication equipment, TV receivers etc.

○ Other high-tech products (HT2): Pharmaceuticals, aerospace, optical/measuring instruments etc.

3) Other transactions (UNC): Electricity, motion picture films, printed material, 'special' transactions, gold, art, coins, pets. This class has not been included in this study.

Based on the idea of Liesner (1958)'s relative export performance, Balassa (1965) has renewed the idea of using export share rates as an index to calculate the comparative advantage. The Balassa index is one of the most used indices for measuring trade performance and is defined as:

$$
R C A_{i j}=\frac{X_{i j}}{\sum_{i=1}^{n} X_{i j}}\left(\frac{\sum_{j=1}^{m} X_{i j}}{\sum_{i=1}^{n} \sum_{j=1}^{m} X_{i j}}\right)^{-1}
$$

Where X: exports, i: sector, j: country, $\mathrm{n}$ : total number of sectors and $\mathrm{m}$ : total number of countries.

The index can take values between zero and infinity. If $R C A>1$ it is stated that this country has the revealed comparative advantage, whereas if $R C A<1$, it has the revealed comparative disadvantage. This happens when the share of this commodity in the exports of the country exceeds the share of exports of the reference group.

The advantage of using this index is that it takes into account the main advantage of a given export commodity and is consistent with changes in the factor equipment and productivity of an economy (Doanh, 2011: 2).

In this study, a classification used by Hinloopen and Marrewijk (2001) is adopted and the RCA index is considered in 4 categories as follows:

$0<R C A \leq 1$ : Products without comparative advantage

$1<R C A \leq 2$ : Products with weak comparative advantage

$2<R C A \leq 4$ : Products with medium comparative advantage

$4<R C A$ : Products with strong comparative advantage

\section{EXPORT SPECIALIZATION LEVELS}

In this section, firstly, revealed comparative advantage index (RCA) for Turkey and SCO member countries during 1993-2016 period is calculated. In doing so, two-year averages 
are presented considering that any random effect could affect the RCA values of a single year. The RCA index values for commodities are classified according to Hinloopen and Marrewijk classification.

In the frequency distributions table of the RCA index, the trimmed mean is also calculated. While calculating trimmed mean (TRMEAN), the maximum and minimum 10\% values of the data are discarded and the average of the remaining data is calculated. In this way, the influence of extreme values are reduced (Van Belle, Fisher, Heagerty, \& Lumley, 2004: 276).

Secondly, the percentage of products with comparative advantage is classified according to technological categories presented by Lall.

The revealed comparative advantage index (RCA) for Turkey is given in Table 4. About $73 \%$ of commodity categories in 1993-1994 has a RCA value greater or equal to unity. The number of such commodity categories has gradually decreased till 2015-2016 period. During these years, the ratio of products with weak comparative advantage increased from $6 \%$ to 11,7 , and the commodity ratio with strong comparative advantage remained at $10 \%$. The percentage of products with medium comparative advantage ranges from $10 \%$ to $15,6 \%$.

Table 4. Frequency Distribution of Turkey's Rca Index

\begin{tabular}{lrrrrrrrrrrrr|}
\hline & $\mathbf{1 9 9 3 -}$ & $\mathbf{1 9 9 5 -}$ & $\mathbf{1 9 9 7 -}$ & $\mathbf{1 9 9 9 -}$ & $\mathbf{2 0 0 1 -}$ & $\mathbf{2 0 0 3 -}$ & $\mathbf{2 0 0 5 -}$ & $\mathbf{2 0 0 7 -}$ & $\mathbf{2 0 0 9 -}$ & $\mathbf{2 0 1 1 -}$ & $\mathbf{2 0 1 3 -}$ & $\mathbf{2 0 1 5 -}$ \\
& $\mathbf{1 9 9 4}$ & $\mathbf{1 9 9 6}$ & $\mathbf{1 9 9 8}$ & $\mathbf{2 0 0 0}$ & $\mathbf{2 0 0 2}$ & $\mathbf{2 0 0 4}$ & $\mathbf{2 0 0 6}$ & $\mathbf{2 0 0 8}$ & $\mathbf{2 0 1 0}$ & $\mathbf{2 0 1 2}$ & $\mathbf{2 0 1 4}$ & $\mathbf{2 0 1 6}$ \\
\hline $\mathbf{0}<\boldsymbol{R C A} \leq \mathbf{1}$ & 185 & 186 & 180 & 177 & 176 & 178 & 168 & 165 & 162 & 163 & 158 & 163 \\
\hline $\mathbf{1}<\boldsymbol{R C A} \leq \mathbf{2}$ & 16 & 19 & 26 & 27 & 31 & 26 & 34 & 31 & 34 & 33 & 37 & 30 \\
\hline $\mathbf{2}<\boldsymbol{R C A} \leq \mathbf{4}$ & 25 & 26 & 21 & 24 & 18 & 27 & 29 & 35 & 36 & 33 & 33 & 40 \\
\hline 4 $<\boldsymbol{R C A}$ & 26 & 26 & 29 & 29 & 30 & 26 & 26 & 24 & 25 & 27 & 28 & 22 \\
\hline TOTAL & 252 & 257 & 256 & 257 & 255 & 257 & 257 & 255 & 257 & 256 & 256 & 255 \\
\hline Mean & 1.42 & 1.40 & 1.40 & 1.40 & 1.30 & 1.30 & 1.37 & 1.30 & 1.41 & 1.46 & 1.50 & 1.38 \\
\hline TRMEAN \%10 & 0.92 & 0.95 & 0.99 & 1.04 & 0.99 & 1.00 & 1.05 & 1.03 & 1.10 & 1.13 & 1.17 & 1.08 \\
\hline Maximum & 20.31 & 18.84 & 17.58 & 15.88 & 11.62 & 10.86 & 19.84 & 14.1 & 18.26 & 19.55 & 20.15 & 22.34 \\
\hline
\end{tabular}

Source: Calculated from UN Comtrade data

While the maximum values of the RCA index decreased in the period 1993-2004, it is increasing after 2004, except for the decrease in 2007-2008 period. Hata! Başvuru kaynağı bulunamadı.5 presents SCO members' revealed comparative advantage index calculations. The share of Russian Federation's products with no comparative advantage is $83.46 \%$ in 1996-1997, and decreased to $78.82 \%$ in 2015-2016. For Russian Federation the ratio of commodities with a strong comparative advantage declined from $7.88 \%$ to $5.88 \%$ in the same period. The ratio of products with weak and medium comparative advantage for Russian Federation increased between 1996-1997 and 2015-2016. 
Table 5. Frequency Distributions of the SCO Members' RCA Index

\begin{tabular}{lcccccccccccc}
\hline & \multicolumn{1}{c}{ Russian Fed. } & \multicolumn{2}{c}{ China } & \multicolumn{2}{c}{ India } & \multicolumn{2}{c}{ Pakistan } & \multicolumn{2}{c}{ Kazakhstan } & \multicolumn{2}{c}{ Kyrgyzstan } \\
\hline & $\mathbf{1 9 9 6 -}$ & $\mathbf{2 0 1 5 -}$ & $\mathbf{1 9 9 3 -}$ & $\mathbf{2 0 1 5 -}$ & $\mathbf{1 9 9 3 -}$ & $\mathbf{2 0 1 5 -}$ & $\mathbf{1 9 9 3 -}$ & $\mathbf{2 0 1 5 -}$ & $\mathbf{1 9 9 5 -}$ & $\mathbf{2 0 1 5}-$ & $\mathbf{1 9 9 5 -}$ & $\mathbf{2 0 1 5 -}$ \\
& $\mathbf{1 9 9 7}$ & $\mathbf{2 0 1 6}$ & $\mathbf{1 9 9 4}$ & $\mathbf{2 0 1 6}$ & $\mathbf{1 9 9 4}$ & $\mathbf{2 0 1 6}$ & $\mathbf{1 9 9 5}$ & $\mathbf{2 0 1 6}$ & $\mathbf{1 9 9 6}$ & $\mathbf{2 0 1 6}$ & $\mathbf{1 9 9 6}$ & $\mathbf{2 0 1 6}$ \\
\hline $\mathbf{0}<\boldsymbol{R} \boldsymbol{C A} \leq \mathbf{1}$ & 212 & 201 & 163 & 156 & 188 & 169 & 186 & 202 & 201 & 218 & 153 & 191 \\
\hline $\mathbf{1}<\boldsymbol{R} \boldsymbol{C A} \leq \mathbf{2}$ & 14 & 21 & 41 & 66 & 24 & 46 & 8 & 8 & 12 & 6 & 27 & 16 \\
\hline $\mathbf{2}<\boldsymbol{R} \boldsymbol{C A} \leq \mathbf{4}$ & 9 & 18 & 34 & 31 & 19 & 26 & 10 & 16 & 11 & 9 & 10 & 11 \\
\hline $\mathbf{4}<\boldsymbol{R} \boldsymbol{C A}$ & 19 & 15 & 19 & 3 & 20 & 17 & 17 & 23 & 24 & 19 & 22 & 12 \\
\hline TOTAL & 254 & 255 & 257 & 256 & 251 & 258 & 221 & 249 & 248 & 252 & 212 & 230 \\
\hline Mean & 0.88 & 0.84 & 1.26 & 0.96 & 1.28 & 1.30 & 1.24 & 1.86 & 1.60 & 1.48 & 2.45 & 0.91 \\
\hline TRMEAN \%10 & 0.52 & 0.58 & 1.01 & 0.87 & 0.78 & 0.95 & 0.34 & 0.62 & 0.74 & 0.43 & 0.75 & 0.38 \\
\hline Maximum & 21.39 & 12.67 & 22.27 & 5.59 & 21.46 & 17.87 & 38.80 & 73.99 & 39.80 & 83.81 & 80.98 & 34.42 \\
\hline
\end{tabular}

Source: Calculated from UN Comtrade data

China's average RCA index between 1993-1994 and 2015-2016 observed that the share of products with strong comparative advantage decreased by $6.22 \%$, while the rate of products with weak comparative advantage increased by $9.83 \%$.

It is evident that, the share of the India's products with no comparative advantage decreased by a total amount of $10.66 \%$ from 1993-1994 to 2015-2016, whilst the ratio of commodity groups with weak and medium comparative advantage increased by $7.24 \%$ and $4.15 \%$, respectively. The commodity ratio with strong comparative advantage decreased from $7.64 \%$ to $6.64 \%$ during these periods.

The share of products for which the Pakistan has no comparative advantage declined from 1993-1995 to 2015-2016. The ratio of products with medium and strong comparative advantage for Pakistan increased in the same period. On the other hand, considering the rate of increase in products Pakistan has comparative advantage, it seems that Pakistan is far behind India.

According to Kazakhstan's RCA values during 1995-1996 and 2015-2016, the number of products with comparative disadvantage increased. It is seen that there is an increase in the number of Kyrgyzstan's products with comparative disadvantage.

Table 6 gives the percentage of products with RCA index higher than unity according to the technology classification for Turkey. The table clearly shows that the proportion of products with revealed comparative advantage increased from $26.59 \%$ in 1993-1994 to $36.08 \%$ in $2015-2016$. This means that there is a decrease in the commodity group which has the revealed comparative disadvantage. The greatest increase in the proportion of products with revealed comparative advantage is in low-tech products (with an increase of $4.23 \%$ ). The amount of increase in the proportion of products with comparative advantage in the mediumtechnology products is $3.46 \%$ between 1993-1994 and 2015-2016. On the other hand, the 
proportion of products with comparative advantage in high-tech products fluctuates between 0.39\% and 0.78\% during the periods 1993-1994 and 2015-2016.

Table 6. Turkey's Proportion of Products with RCA Index Higher than Unity (\%)

\begin{tabular}{|c|c|c|c|c|c|c|c|c|c|c|c|c|}
\hline & $\begin{array}{l}\text { 1993- } \\
1994\end{array}$ & $\begin{array}{l}1995- \\
1996\end{array}$ & $\begin{array}{c}1997- \\
1998\end{array}$ & $\begin{array}{c}\text { 1999- } \\
2000 \\
\end{array}$ & $\begin{array}{l}\text { 2001- } \\
2002 \\
\end{array}$ & $\begin{array}{c}2003- \\
2004 \\
\end{array}$ & $\begin{array}{l}2005- \\
2006 \\
\end{array}$ & $\begin{array}{c}2007- \\
2008 \\
\end{array}$ & $\begin{array}{l}2009- \\
2010 \\
\end{array}$ & $\begin{array}{l}\text { 2011- } \\
2012 \\
\end{array}$ & $\begin{array}{c}2013- \\
2014 \\
\end{array}$ & $\begin{array}{c}2015- \\
2016 \\
\end{array}$ \\
\hline PM & 5.95 & 5.84 & 6.64 & 5.84 & 5.49 & 5.45 & 5.84 & 5.10 & 5.45 & 4.69 & 5.08 & 5.49 \\
\hline RB & 7.54 & 8.17 & 8.59 & 8.95 & 8.63 & 7.00 & 8.17 & 8.63 & 8.56 & 8.59 & 9.77 & 9.02 \\
\hline LT & 7.14 & 8.17 & 8.59 & 9.34 & 9.80 & 10.12 & 11.28 & 10.98 & 11.28 & 12.11 & 11.72 & 11.37 \\
\hline MT & 5.56 & 5.06 & 5.47 & 6.23 & 6.67 & 7.78 & 8.95 & 9.41 & 10.51 & 9.77 & 10.55 & 9.02 \\
\hline HT & 0.40 & 0.39 & 0.39 & 0.78 & 0.39 & 0.39 & 0.39 & 0.78 & 0.78 & 0.78 & 0.78 & 0.78 \\
\hline Total & 26.5 & 27.63 & 29.69 & 31.13 & 30.98 & 30.74 & 34.63 & 35.29 & 36.96 & 36.33 & 38.28 & 36.08 \\
\hline
\end{tabular}

Source: Calculated from UN Comtrade data

In Table 7.7 it is seen that the share of goods for Russian Federation has revealed comparative advantage increased from $16.54 \%$ in to $21.18 \%$ in $2015-2016$. Additionally, it is shown that the proportion of primary and resource based products with a revealed comparative advantage is also increased between these years. While it is noticed that there is no change in the comparative advantage rates in the high technology and low technology products, competitiveness in medium technology products has declined.

Table 7. Russian Federation's Proportion of Products with RCA Index Higher than Unity

\begin{tabular}{|c|c|c|c|c|c|c|c|c|c|c|c|}
\hline & $\begin{array}{l}\text { 1996- } \\
1997\end{array}$ & $\begin{array}{c}1998- \\
1999\end{array}$ & $\begin{array}{l}2000- \\
2001\end{array}$ & $\begin{array}{l}2002- \\
2003\end{array}$ & $\begin{array}{l}2004- \\
2005\end{array}$ & $\begin{array}{l}\text { 2006- } \\
2007\end{array}$ & $\begin{array}{c}\text { 2008- } \\
2009\end{array}$ & $\begin{array}{c}2010- \\
2011\end{array}$ & $\begin{array}{l}2012- \\
2013\end{array}$ & $\begin{array}{c}2014- \\
2015\end{array}$ & $\begin{array}{c}2015- \\
2016\end{array}$ \\
\hline$\overline{\mathbf{P M}}$ & 5.91 & 5.88 & 4.71 & 4.37 & 4.35 & 4.76 & 4.78 & 6.30 & 7.84 & 7.45 & 8.24 \\
\hline RB & 5.12 & 6.27 & 5.10 & 4.76 & 4.35 & 4.76 & 4.78 & 3.54 & 4.71 & 6.67 & 8.24 \\
\hline LT & 1.18 & 2.35 & 1.57 & 1.19 & 1.19 & 1.19 & 1.20 & 0.79 & 1.18 & 1.18 & 1.18 \\
\hline MT & 2.76 & 3.92 & 3.92 & 3.17 & 2.37 & 1.98 & 1.59 & 1.18 & 1.96 & 1.96 & 1.96 \\
\hline HT & 0.79 & 1.18 & 0.78 & 1.59 & 0.79 & 0.40 & 0.40 & 0.39 & 0.39 & 0.78 & 0.78 \\
\hline Total & 16.54 & 20.78 & 16.47 & 15.87 & 13.83 & 13.49 & 13.15 & 12.99 & 16.08 & 18.43 & 21.18 \\
\hline
\end{tabular}

Source: Calculated from UN Comtrade data

In

Table 8., when comparing the proportions of products with comparative advantage of China, it is seen that there is a decrease in the number of products with comparative advantage in primary products and resource-based products from 1993-1994 to 2015-2016. On the other hand, the increase in the number of products with technology-based products is noticeable. Particularly, there is an increase of $7.44 \%$ in medium-technology products indicating that China has increased the number of products with comparative advantage in this commodity category. 
Table 8. China's Proportion of Products with RCA Index Higher than Unity (\%)

\begin{tabular}{|c|c|c|c|c|c|c|c|c|c|c|c|c|}
\hline & $\begin{array}{l}\text { 1993- } \\
1994\end{array}$ & $\begin{array}{l}1995- \\
1996\end{array}$ & $\begin{array}{c}1997- \\
1998\end{array}$ & $\begin{array}{l}1999- \\
2000\end{array}$ & $\begin{array}{l}2001- \\
2002\end{array}$ & $\begin{array}{l}\text { 2003- } \\
2004 \\
\end{array}$ & $\begin{array}{l}2005- \\
2006\end{array}$ & $\begin{array}{l}2007- \\
2008\end{array}$ & $\begin{array}{l}2009- \\
2010\end{array}$ & $\begin{array}{l}\text { 2011- } \\
2012\end{array}$ & $\begin{array}{c}2013- \\
2014 \\
\end{array}$ & $\begin{array}{l}2015- \\
2016\end{array}$ \\
\hline PM & 9.73 & 8.53 & 8.17 & 7.81 & 7.42 & 6.23 & 3.88 & 2.33 & 2.72 & 2.73 & 2.73 & 1.95 \\
\hline RB & 7.78 & 6.98 & 6.61 & 5.47 & 5.47 & 5.45 & 6.20 & 6.23 & 6.23 & 7.03 & 6.64 & 6.25 \\
\hline LT & 12.06 & 12.02 & 12.06 & 12.50 & 12.89 & 12.84 & 13.18 & 14.79 & 14.01 & 15.23 & 15.23 & 15.23 \\
\hline MT & 3.89 & 4.65 & 5.45 & 6.64 & 6.25 & 5.84 & 8.14 & 8.95 & 9.73 & 11.33 & 11.33 & 11.33 \\
\hline HT & 3.11 & 3.88 & 3.89 & 4.30 & 4.69 & 3.50 & 3.49 & 3.89 & 4.28 & 4.69 & 4.69 & 4.30 \\
\hline Total & 36.58 & 36.43 & 36.58 & 37.11 & 37.50 & 33.85 & 34.88 & 36.19 & 36.96 & 41.02 & 40.63 & 39.06 \\
\hline
\end{tabular}

Source: Calculated from UN Comtrade data

Table 9 shows the changes in the proportion of products with comparative advantage for India. Especially in medium-tech products, comparative advantage has reached $5.47 \%$ with a consistent increase starting from $1.99 \%$. Similarly, there is an increase in comparative advantage for resource-based products. The number of products with comparative advantage in high technology products remained constant over the years.

Table 9. India's Proportion of Products with RCA Index Higher than Unity (\%)

\begin{tabular}{|c|c|c|c|c|c|c|c|c|c|c|c|c|}
\hline & $\begin{array}{l}\text { 1993- } \\
1994 \\
\end{array}$ & $\begin{array}{l}1995- \\
1996 \\
\end{array}$ & $\begin{array}{c}1997- \\
1998\end{array}$ & $\begin{array}{c}1999- \\
2000\end{array}$ & $\begin{array}{l}2001- \\
2002\end{array}$ & $\begin{array}{c}2003- \\
2004\end{array}$ & $\begin{array}{c}2005- \\
2006\end{array}$ & $\begin{array}{l}2007- \\
2008\end{array}$ & $\begin{array}{c}2009- \\
2010\end{array}$ & $\begin{array}{l}\text { 2011- } \\
2012\end{array}$ & $\begin{array}{c}\text { 2013- } \\
2014\end{array}$ & $\begin{array}{c}2015- \\
2016\end{array}$ \\
\hline PM & 7.17 & 9.16 & 8.30 & 7.84 & 8.17 & 9.34 & 9.34 & 9.34 & 9.69 & 9.34 & 10.08 & 9.38 \\
\hline RB & 5.18 & 6.77 & 5.93 & 7.06 & 8.17 & 8.95 & 8.95 & 8.95 & 8.14 & 8.56 & 8.91 & 9.38 \\
\hline LT & 9.96 & 9.16 & 10.28 & 11.37 & 10.89 & 11.28 & 10.89 & 9.73 & 8.53 & 8.95 & 9.30 & 9.77 \\
\hline MT & 1.99 & 2.79 & 1.98 & 2.75 & 3.11 & 4.28 & 4.28 & 5.06 & 4.65 & 5.06 & 5.04 & 5.47 \\
\hline HT & 0.40 & 0.40 & 0.79 & 0.78 & 1.17 & 1.17 & 0.39 & 1.17 & 0.39 & 0.39 & 0.78 & 0.78 \\
\hline Total & 25.10 & 28.69 & 27.67 & 30.20 & 31.91 & 35.80 & 35.02 & 35.02 & 32.17 & 32.68 & 34.50 & 35.16 \\
\hline
\end{tabular}

Source: Calculated from UN Comtrade data

Pakistan doesn't have comparative advantage in high-tech products. Among the countries surveyed, Pakistan is the only country that does not have comparative advantage in high technology commodities.

Table 10. Pakistan's Proportion of Products with RCA Index Higher than Unity (\%)

\begin{tabular}{|c|c|c|c|c|c|c|c|c|c|c|c|c|}
\hline & $\begin{array}{l}1994- \\
1995\end{array}$ & $\begin{array}{l}1996- \\
1997\end{array}$ & $\begin{array}{c}1998- \\
1999\end{array}$ & $\begin{array}{l}2000- \\
2001\end{array}$ & $\begin{array}{l}2002- \\
2003\end{array}$ & $\begin{array}{l}2004- \\
2005\end{array}$ & $\begin{array}{l}2006- \\
2007\end{array}$ & $\begin{array}{c}2008- \\
2009\end{array}$ & $\begin{array}{c}2010- \\
2011\end{array}$ & $\begin{array}{l}2012- \\
2013\end{array}$ & $\begin{array}{c}2014- \\
2015\end{array}$ & $\begin{array}{c}2015- \\
2016\end{array}$ \\
\hline$\overline{\mathbf{P M}}$ & 5.43 & 5.74 & 4.98 & 5.43 & 5.06 & 4.51 & 4.78 & 5.18 & 6.80 & 8.06 & 6.48 & 5.62 \\
\hline RB & 2.26 & 2.39 & 3.17 & 3.17 & 3.38 & 5.33 & 4.78 & 3.59 & 5.20 & 4.44 & 4.45 & 4.42 \\
\hline LT & 6.79 & 6.70 & 7.24 & 7.24 & 6.75 & 7.38 & 6.77 & 7.57 & 6.40 & 6.45 & 6.88 & 6.83 \\
\hline MT & 1.36 & 1.44 & 1.36 & 1.81 & 2.53 & 2.87 & 2.79 & 2.39 & 2.40 & 2.42 & 2.43 & 2.01 \\
\hline HT & 0.00 & 0.00 & 0.00 & 0.00 & 0.00 & 0.00 & 0.00 & 0.00 & 0.00 & 0.00 & 0.00 & 0.00 \\
\hline Total & 15.84 & 16.27 & 16.74 & 17.65 & 17.72 & 20.08 & 19.12 & 18.73 & 20.80 & 21.37 & 20.24 & 18.88 \\
\hline
\end{tabular}

Source: Calculated from UN Comtrade data

It is also seen that there is a $5.46 \%$ decrease in total number of products in which

Kazakhstan has comparative advantage (see 
Table 1111).

Table 11. Kazakhstan's Proportion of Products with RCA Index Higher than Unity (\%)

\begin{tabular}{|c|c|c|c|c|c|c|c|c|c|c|c|}
\hline & $\begin{array}{c}\text { 1995- } \\
1996 \\
\end{array}$ & $\begin{array}{l}\text { 1997- } \\
1998 \\
\end{array}$ & $\begin{array}{l}1999- \\
2000 \\
\end{array}$ & $\begin{array}{c}\text { 2001- } \\
2002 \\
\end{array}$ & $\begin{array}{l}2003- \\
2004 \\
\end{array}$ & $\begin{array}{c}2005- \\
2006 \\
\end{array}$ & $\begin{array}{l}2007- \\
2008 \\
\end{array}$ & $\begin{array}{c}2009- \\
2010 \\
\end{array}$ & $\begin{array}{l}\text { 2011- } \\
2012 \\
\end{array}$ & $\begin{array}{l}2013- \\
2014 \\
\end{array}$ & $\begin{array}{c}2015- \\
2016 \\
\end{array}$ \\
\hline $\mathbf{P M}$ & 7.66 & 6.88 & 5.33 & 6.45 & 6.50 & 5.76 & 5.58 & 6.05 & 6.00 & 6.00 & 6.75 \\
\hline RB & 6.45 & 4.86 & 4.10 & 4.84 & 5.28 & 4.12 & 4.78 & 4.44 & 3.20 & 3.20 & 4.37 \\
\hline LT & 1.61 & 0.81 & 0.82 & 1.21 & 1.63 & 1.65 & 1.20 & 1.21 & 0.80 & 0.80 & 0.79 \\
\hline MT & 2.82 & 2.43 & 1.23 & 1.21 & 1.22 & 1.23 & 0.80 & 0.81 & 0.80 & 0.80 & 0.79 \\
\hline HT & 0.40 & 0.40 & 0.41 & 0.40 & 0.41 & 0.41 & 0.40 & 0.40 & 0.40 & 0.40 & 0.40 \\
\hline Total & 18.95 & 15.79 & 12.70 & 14.52 & 15.85 & 13.58 & 13.15 & 13.31 & 11.60 & 11.20 & 13.49 \\
\hline
\end{tabular}

Source: Calculated from UN Comtrade data

Table 12 shows the technological classification of products that Kyrgyzstan has comparative advantage. During the years 1995-1996 and 2015-2016, a decrease of $10.87 \%$ in total is observed, meaning that Kyrgyzstan has lost its competitiveness, especially in resourcebased and low technology commodities.

Table 12. Kyrgyzstan's Proportion of Products with RCA Index Higher than Unity (\%)

\begin{tabular}{lccccccccrrr}
\hline & $\begin{array}{c}\text { 1995- } \\
\mathbf{1 9 9 6}\end{array}$ & $\begin{array}{c}\mathbf{1 9 9 8}- \\
\mathbf{1 9 9 9}\end{array}$ & $\begin{array}{c}\mathbf{2 0 0 0 -} \\
\mathbf{2 0 0 1}\end{array}$ & $\begin{array}{c}\mathbf{2 0 0 2}- \\
\mathbf{2 0 0 3}\end{array}$ & $\begin{array}{c}\mathbf{2 0 0 4}- \\
\mathbf{2 0 0 5}\end{array}$ & $\begin{array}{c}\mathbf{2 0 0 6}- \\
\mathbf{2 0 0 7}\end{array}$ & $\begin{array}{c}\mathbf{2 0 0 8}- \\
\mathbf{2 0 0 9}\end{array}$ & $\mathbf{2 0 1 0 -}$ & $\mathbf{2 0 1 1}$ & $\mathbf{2 0 1 3}$ & $\mathbf{2 0 1 5 -}$ \\
\hline PM & 6.60 & 5.24 & 5.60 & 5.68 & 6.61 & 6.58 & 5.17 & 6.25 & 6.17 & 5.65 \\
\hline RB & 9.91 & 6.55 & 6.47 & 6.99 & 5.73 & 7.02 & 5.17 & 5.36 & 6.61 & 4.78 \\
\hline LT & 7.08 & 2.18 & 1.29 & 2.62 & 3.08 & 3.07 & 2.59 & 3.13 & 4.85 & 3.04 \\
\hline MT & 2.83 & 3.06 & 2.16 & 0.87 & 1.32 & 1.32 & 0.00 & 0.89 & 2.64 & 2.17 \\
\hline HT & 0.94 & 0.87 & 0.86 & 0.44 & 0.88 & 0.44 & 0.43 & 0.00 & 0.44 & 0.43 \\
\hline Total & 27.83 & 19.21 & 17.24 & 17.47 & 18.50 & 19.30 & 14.66 & 16.96 & 21.59 & 16.96 \\
\hline
\end{tabular}

Source: Calculated from UN Comtrade data

\section{COMPARISON OF COMPARATIVE ADVANTAGES OF TURKEY AND SCO MEMBERS}

Comparing Turkey's average RCA index during the period 2015-2016 with those of the SCO member's for products with strong comparative advantage is important in terms of determining the competitiveness of Turkey and its competitors in this market.

In 
Table 1313, 22 products in which Turkey has strong comparative advantage are given alongside the average RCA index values of SCO countries during the 2015-2016 period. It can be seen that Russian Federation has comparative advantage in only 2 of these 22 products, 278 "other raw minerals and 676 "Iron or steel (alloyed, unalloyed) wire rods, rods and profiles".

When Turkey and China are compared, it is seen that there are 14 products that Turkey shares comparative advantage with China. China has a RCA value of three in 4 of these products that is India also has a strong comparative advantage. These products can be listed as follows: 655 "Knitted or crocheted fabrics (including tubular knit fabrics, n.e.s., pile fabrics and openwork fabrics), n.e.s.", 846 "clothing accessories, of textile fabrics, whether or not knitted or crocheted (other than those for babies)", 652 "cotton fabrics, woven (not including narrow or special fabrics)", 844 "under garments not knit". Taking these figures into consideration, it can be concluded that Turkey competes with China in products especially in clothing and accessories.

When Turkey and India are put side by side, India has also comparative advantage in 13 out of 22 products in which Turkey has a strong comparative advantage. India has a RCA value of four in 2 of these products that is India also has a strong comparative advantage. These products are 659 "Floor coverings etc." and 273 "Stone, sand and gravel".

Looking at the RCA averages of Turkey and Pakistan, it is seen that Pakistan has comparative advantage in 13 of the products Turkey has strong comparative advantage. Of these 8, Pakistan has also strong comparative advantage. Among these products are 046 "Meal and flour of wheat and flour of meslin", with a mean value of RCA of 57.94. The second and third highest average RCA values belong to 062 "Sugar confectionery" and 273 "Stone, sand and gravel".

Turkey shares strong competitiveness only in 2 products with Kazakhstan. These are 046 "Meal and flour of wheat and flour of meslin" and 278 "Other crude minerals". Other than these products Kazakhstan doesn't have competitiveness among the commodities Turkey has strong comparative advantage. 
Kyrgyzstan has a comparative advantage in 5 out of 22 in which Turkey has a strong comparative advantage. These products consist of 661 "Lime, cement, natural stones, asphalt and related goods", 273 "Stone, sand and gravel", 057 "Fruit and nuts (excluding oil nuts), fresh or dried" and 278 "Other raw minerals".

China, India and Pakistan are the main competitors in products where Turkey has a strong comparative advantage among low-tech, medium-technology products.

In the case of resource based products, it is seen that India and Pakistan have comparative advantage. In the case of primary products, Turkey competes with Kyrgyzstan.

Table 13. RCA Index Comparisons between Turkey and SCO Countries for 20152016

\begin{tabular}{|c|c|c|c|c|c|c|c|c|}
\hline $\begin{array}{c}\text { Commodity } \\
\text { Codes }\end{array}$ & Class & Turkey & $\begin{array}{c}\text { Russian } \\
\text { Fed. }\end{array}$ & China & India & Pakistan & Kazakhstan & Kyrgyzstan \\
\hline 046 & RB1 & 22.34 & 0.80 & 0.09 & 1.26 & 57.94 & 37.26 & 0.03 \\
\hline 659 & LT1 & 15.01 & 0.07 & 1.31 & 7.23 & 5.91 & 0.04 & 0.24 \\
\hline 273 & PM & 11.76 & 0.18 & 0.30 & 5.74 & 13.88 & 0.61 & 2.87 \\
\hline $\mathbf{0 2 5}$ & PM & 6.87 & 0.21 & 0.31 & 1.43 & 2.68 & 0.53 & 0.03 \\
\hline 058 & RB1 & 6.70 & 0.31 & 1.00 & 0.84 & 0.30 & 0.04 & 0.21 \\
\hline 676 & LT2 & 6.62 & 1.20 & 1.83 & 0.80 & 0.02 & 0.36 & 0.48 \\
\hline 812 & MT3 & 6.61 & 0.21 & 1.80 & 0.38 & 0.14 & 0.15 & 0.02 \\
\hline 583 & MT2 & 6.10 & 0.66 & 0.60 & 0.47 & 0.18 & 0.11 & 0.41 \\
\hline 661 & RB2 & 5.88 & 0.46 & 1.98 & 2.73 & 5.84 & 0.20 & 3.17 \\
\hline 278 & PM & 5.18 & 1.04 & 1.07 & 2.38 & 4.82 & 4.18 & 2.12 \\
\hline 047 & RB1 & 5.05 & 0.54 & 0.01 & 1.57 & 2.25 & 0.71 & 0.01 \\
\hline 655 & LT1 & 4.80 & 0.02 & 3.12 & 0.45 & 0.88 & 0.00 & 0.07 \\
\hline 057 & $\mathrm{PM}$ & 4.71 & 0.03 & 0.39 & 0.96 & 3.40 & 0.05 & 2.22 \\
\hline 846 & LT1 & 4.46 & 0.05 & 3.17 & 2.07 & 5.09 & 0.04 & 0.34 \\
\hline 844 & LT1 & 4.32 & 0.03 & 3.31 & 1.66 & 3.70 & 0.03 & 2.37 \\
\hline 062 & RB1 & 4.28 & 0.61 & 0.71 & 0.51 & 36.07 & 0.87 & 0.43 \\
\hline 613 & LT1 & 4.23 & 0.12 & 1.05 & 0.02 & 0.26 & 0.01 & 0.22 \\
\hline 845 & LT1 & 4.16 & 0.03 & 2.45 & 2.61 & 3.45 & 0.02 & 0.22 \\
\hline 693 & LT2 & 4.16 & 0.27 & 1.62 & 1.56 & 0.03 & 0.07 & 0.63 \\
\hline 652 & LT1 & 4.14 & 0.07 & 3.45 & 3.48 & 6.37 & 0.11 & 0.15 \\
\hline 775 & MT3 & 4.11 & 0.23 & 2.66 & 0.18 & 0.05 & 0.02 & 0.50 \\
\hline 532 & RB2 & 4.11 & 0.04 & 0.54 & 1.74 & 0.04 & 0.00 & 0.01 \\
\hline
\end{tabular}

\section{CONCLUSION}


SCO is an integration movement established in the 1990s with security concerns and political reasons, but nowadays attracting economic attention due to the rapid economic development of some of the countries in the region and has recently started to be on the agenda of Turkey.

China, Russia and India have a serious economic weight in the region which is the third biggest zone in terms of production after the US and the European Union. SCO, which does not have a large share in Turkey's exports, does have an important place in its imports.

In the study, Balassa's Revealed Comparative Advantage Index of Turkey and SCO countries is analysed by using the Standard International Trade Classification Revision 3 3digit commodity group data and Lall's (2000) technology classification (SITC Rev. 3). According to empirical findings China, Turkey and India received the first three rankings in the proportion of number of commodities with RCA greater to unity to all products. In terms of technological subclasses, India, Turkey and Russia have highest proportion of products with RCA Index higher than unity in resource based commodities.

China, Turkey and India are the first 3 countries in the share of all products which possess comparative advantage for low technology and medium technology products. The ratio of products with RCA index higher than unity in high-technology products to all products is $4.08 \%$ in China while it is lower than $1 \%$ for Turkey and other SCO countries, and Pakistan has no comparative advantage in this commodity group. This is not surprising given China's 32.75\% share of high-tech products in exports in 2016.

It is seen that China, India and Pakistan have also comparative advantage in low and medium technology products in which Turkey enjoy strong comparative advantage. For resource-based products where Turkey has a strong comparative advantage, India and Pakistan are among the countries with high RCA index averages; it is seen that Kyrgyzstan also holds high RCA index values for resource based products.

To summarize, the products and technological categories Turkey and SCO members compete carry similarities. Of the SCO members, only China is distinguished from Turkey and other SCO members by having comparative advantage in high technology products. The policies that China has developed to support high-tech industries are influential in its competitiveness. The ratio of China's expenditure on research and development (R\&D) to GDP is $2.1 \%$ in 2016, more than Turkey and other SCO members. In the same period, Turkey's R\&D expenditures are $0.94 \%$ of GDP. Russia, Kazakhstan and Kyrgyzstan are separated from Turkey and other members of SCO because of their comparatively low RCA index in low and medium technology products. Since Turkey has higher labour costs that 
determine competitiveness in low-tech products, it is necessary to shift the production model towards medium and high-tech products rather than trying to maintain comparative advantage in low-tech products against China and India.

\section{REFERENCES}

Balassa, B. (1965). Trade liberalisation and "revealed" comparative advantage. The Manchester School of Economic and Social Studies, 33(2), 99-123.

Çiçek, R., \& Bashimov, G. (2016). Orta Asya'nın pamuk ticaretindeki karşılaştırmalı üstünlüğünün belirlenmesi. Uluslararası Yönetim İktisat ve Isşletme Dergisi, 12(28), 1-14.

Doanh, N. K. (2011). The dynamic patterns of Korea's export specialization. Vietnam: Thai Nguyen University of Economics and Business Administration, 177-198.

Eğilmez, M. (2016). Şangay İşbirliği Örgütü ve Türkiye, http://www.mahfiegilmez.com/2016/11/sangayisbirligi-orgutu-ve-turkiye.html, 25.08.2017

Erkan, B. (2012). BRIC ülkeleri ve Türkiye'nin ihracat uzmanlaşma ve rekabet düzeylerinin karșılaştırmalı analizi. AIB $\ddot{U}-\dot{I} \dot{B} B F$ Ekonomik ve Sosyal Araştırmalar Dergisi, Bahar 2012, 8(1), 101-131.

Grace, A. (2016), Quantifying China's influence on the Shanghai Cooperation Organization, Cornell International Affairs Review, Vol.10, No.1, 1-3

Hinloopen, J., \& Van Marrewijk, C. (2001). On the empirical distribution of the Balassa index. Weltwirtschaftliches Archiv, 137(1), 1-35.

IMF (2017). World Economic Outlook April http://www.imf.org/external/pubs/ft/weo/2017/01/weodata/weoselgr.aspx, 15.07.2017.

Kaya, A. A. (2006). İmalat sanayi ihracatında uzmanlaşma: Türkiye-Avrupa Birliği analizi (1991-2003). Ege Academic Review, Vol.6, Issue 2, 73-82.

Khatibi, A. (2008). Kazakhstan's revealed comparative advantage vis-à-vis the EU-27. ECIPE Working Paper No. $03 / 2008$.

Kösekahyaoğlu, L. ve Özdamar, G. (2011). Türkiye, Çin ve Hindistan'ın sektörel rekabet gücü üzerine karşılaştırmalı bir inceleme, Uludă̆ Üniversitesi İktisadi ve İdari Bilimler Fakültesi Dergisi, 30(2), 2949.

Lall, S. (2000). The technological structure and performance of developing country manufactured exports, 198598. Oxford development studies, 28(3), 337-369.

Liesner, H. H. (1958). The European common market and British industry. The Economic Journal, 68(270), 302316.

Lord, M. (2015). Regional economic integration in Central Asia and South Asia, MPRA Paper No. 66436.

Raghuramapatruni, R. (2015). Revealed comparative advantage and competitiveness: A study on BRICS, Arabian Journal of Business and Management Review, 5(5), 1-7.

Shoufeng, C., Feng, L., \& Zhang, J. (2011). Export competitiveness of agri-products between China and central Asian countries: A comparative analysis. Canadian Social Science, 7(5), 129-134.

Şahin, D. (2016). Açıklanmış karşılaştırmalı üstünlükler yöntemi ile Türkiye ve Çin'in sektörel rekabet gücünün karşılaştırmalı analizi. Kırıkkale Üniversitesi Sosyal Bilimler Dergisi, 6(1), 275-289.

Şimşek, N., \& Sadat, S. A. (2009). ECO pazarında Türkiye: 1997-2005 dönemi rekabet gücü analizi. Sosyoekonomi, 10(10), 135-157.

Şimşek, N., Seymen, D. ve Utkulu, U. (2010). Turkey's competitiveness in the EU market: A comparison of different trade measures, Dokuz Eylül Üniversitesi Sosyal Bilimler Enstitüsü Dergisi, 12(2), 107-139.

Şimşek, N., Şimşek, H. A., \& Nurbayev, D. (2017). Kazakhstan's competitiveness in the Eurasian Economic Union market. Sosyoekonomi, Vol. 25(33), 81-102.

Tabata, S. (2006). Observations on changes in Russia's comparative advantage, 1994-2005. Eurasian Geography and Economics, 47(6), 747-759.

Taneja, K., \& Wani, N. U. H. (2014). Economic performance of Indo-China merchandise trade: An analysis of RCA and RID approaches. Journal of International Economics, 5(1), 88.

The World Bank (2017). http://data.worldbank.org/indicator, 29.07.2017.

Turkish Statistical Institute (2017), Main statistics, http://www.tuik.gov.tr/UstMenu.do?metod=temelist, 29.07.2017

UN Comtrade (2017). https://comtrade.un.org/data/, 01.05.2017.

UNCTADSTAT (2017), SITC rev.3 products, by technological categories (Lall (2000)), https://unctadstat.unctad.org/en/Classifications/DimSitcRev3Products_Ldc_Hierarchy.pdf

Van Belle, G., Fisher, L. D., Heagerty, P. J., \& Lumley, T. (2004). Biostatistics: A methodology for the health sciences (Vol. 519): John Wiley \& Sons. 
Veeramani, C. (2008). India and China changing patterns of comparative advantage? In R. Radhakrishna (Ed.), India Development Report 2008, (pp. 145-156). New Delhi, India: Oxford University Press.

Yıldırım, B. (2007). Şanghay İşbirliği Örgütü ve Türkiye, http://www.tasam.org/trTR/Icerik/283/sangay_isbirligi_orgutu_ve_turkiye, 21.08.2017

\section{TÜRKÇE GENIŞ ÖZET}

Şanghay İşbirliği Örgütü (Şî̈) yaklaşık 20 yıl önce Orta Asya bölgesinde ortaya çıkan ve son birkaç yıldır Türkiye'nin de gündeminde yer almaya başlayan bir bölgesel entegrasyon oluşumudur. Üretim açısından dünyada $\mathrm{ABD}$ ve Avrupa Birliği’nden sonra üçüncü sırada gelen bölgenin Türkiye'nin ihracatında fazla bir payı olmamakla birlikte, ithalatında önemli bir yeri bulunmaktadır. Özellikle son dönemlerde Türkiye-AB ilişkilerinde yaşanan bazı sıkıntılar, çeşitli kesimler tarafından ŞiÖ’nün Türkiye için AB'ye ileride olası bir alternatif anlamında dillendirilmesine yol açmıştır. Bu çalışmanın amacı, 1990'lı yıllarda Çin'in öncülüğünde güvenlik kaygısı ve siyasal nedenlerle kurulan, ancak günümüzde bölge ülkelerinin bazılarının hızlı ekonomik gelişimiyle birlikte ekonomik olarak da dikkat çeken Şanghay İşbirliği Örgütü bölgesi ülkeleriyle Türkiye'nin dış ticaretteki rekabet gücü benzerlik ve farklılıklarını karşılaştırmalı olarak ortaya koymaktır.

Çalışmada, ŞïÖ bölgesi ülkeleriyle Türkiye'nin ihracat uzmanlaşma ve rekabet düzeyleri, ürün ve Lall (2000) tabanlı teknolojik kategoriler açısından karşılaştırmalı olarak analiz edilmiştir. Balassa'nın Açıklanmış Karşılaştırmalı Üstünlük Endeksi (RCA) kullanılarak yapılan hesaplamalar sonucunda, RCA endeks ortalamaları birden büyük olan ürünlerin tüm ihraç ürünlere oranlarında ilk üç sırayı Çin, Türkiye ve Hindistan'ın aldığı görülmüştür. Teknolojik alt sınıflara bakıldığında kaynak tabanlı mamul mallarda Hindistan, Türkiye ve Rusya lider konumdadır. Çin, Türkiye ve Hindistan, düşük teknolojili ve orta teknolojili ürünlerin tüm ürünlere paylarında da ilk üç ülkedir. İleri teknolojili ürünlerin tüm ürünlere oranı Çin'de \% 4,08 iken, Türkiye ve diğer ŞiÖ ülkeleri için \% 1'lerden düşük seviyededir. Pakistan'ın ise bu ürün grubundaki hiçbir üründe karşılaştırmalı üstünlüğü bulunmamaktadır. Türkiye'nin güçlü karşılaştırmalı üstünlüğe sahip olduğu ürünlerin RCA endeks ortalamalarının ŞïÖ üye ülkeleri ile karşılaştırılması, özellikle bu pazarda Türkiye’nin rakiplerinin ve pazardaki potansiyelinin belirlenmesi açısından önem arz etmektedir. Türkiye'nin RCA endeks ortalamalarına bakıldığında, güçlü karşılaştırmalı üstünlüğe sahip olduğu düşük ve orta teknolojili ürünlerde Çin, Hindistan ve Pakistan'ın da karşılaştırmalı üstünlügünün olduğu görülmektedir. Türkiye'nin güçlü karşılaştırmalı üstünlüğe sahip olduğu kaynak tabanlı ürünlerde ise birden büyük RCA endeks ortalaması olan ülkeler Hindistan ve Pakistan iken; kaynak tabanlı ürünlerde bu özelliğe sahip ülkenin Kırgızistan olduğu göze çarpmaktadır. 
Önemli rakibi durumunda olan Çin’le kıyaslandığında, Türkiye’nin güçlü karşılaştırmalı üstünlügünün olduğu ürün sayısı 14'tür. Bu ürünler arasında, Çin'in orta karşılaştırmalı üstünlüğe sahip olduğu ürünler; 655 (ürün kodlu) "örme mensucat”, 846 "giyim eşyası, iç aksesuar ve giyim eşyası parçaları (çorap, mendil, eldiven vb.)”, 844 "kadın/kız çocuklar için örme giyim eşyası", 652 "pamuklu mensucat” ile 775 "evlerde kullanılan elektrikli veya elektriksiz diğer makinalar” sektörleridir. Bu rakamlara bakılarak, özellikle giyim eşyaları ve aksesuarları ürün grubunda yer alan ürünlerde Türkiye'nin Çin ile rekabet ettiği sonucu çıkarılabilir. Türkiye ile Hindistan karşılaştırıldığında ise, Türkiye'nin güçlü karşılaştırmalı üstünlüğünün olduğu 22 üründen 13'ünde Hindistan'1n da üstünlüğü vardır. Bu ürünlerden iki tanesinde Hindistan'ın RCA değerinin de dörtten büyük olduğu görülmektedir. Bu ürünler 659 "Halılar ve diğer yer kaplamaları" ile 273 “Taş, mermer, alçı taşı, kireç taşı, kum” dur. Türkiye ile Pakistan'ın RCA ortalamalarına bakıldığında, Pakistan'ın da 13 ürünle Türkiye'nin güçlü karşılaştırmalı üstünlüğe sahip olduğu ürünlerde karşılaştırmalı avantajının olduğu görülmektedir. Bunların sekiz tanesinde Pakistan da güçlü karşılaştırmalı üstünlüğe sahiptir. Bu ürünler arasında 046 "Buğday ve mahlût unu, bulgur, irmik ve pellet" 57,94'lük RCA ortalama değeriyle göze çarpmaktadır. 062 "Şeker mamulleri” ile 273 "Taş, mermer, alçı taşı, kireç taşı, kum” ürünlerinin RCA ortalaması ilk üçte yer almaktadır. Örgütün diğer iki üyesinden Kırgızistan, Türkiye'nin güçlü karşılaştırmalı üstünlüğe sahip olduğu 22 üründen 5 tanesinde karşılaştırmalı üstünlüğe sahipken; Kazakistan'ın iki ürün (046 “Buğday ve mahlût unu, bulgur, irmik ve pellet" ve 278 "Diğer ham mineraller") dışında karşılaştırmalı üstünlüğünün olduğu ürün bulunmamaktadır.

Türkiye ile Şî̈ üyelerinin karşılaştırmalı üstünlüğe sahip oldukları ürünler ve teknolojik sınıflar benzerlik arz etmektedir. ŞïÖ üyelerinden sadece Çin, ileri teknolojili ürünlerde karşılaştırmalı üstünlüğe sahip olduğu ürün oranı ile Türkiye ve Şı̇Ö üyelerinden ayrılmaktadır. Çin'in ileri teknolojili ürünlerdeki bu başarısında, bu tür ürün sanayilerinin desteklenmesine yönelik geliştirdiği politikaların etkili olduğu değerlendirilmektedir. Çin'in araştırma ve geliştirmeye yaptığı harcamaların GSYH'ya oranı Türkiye ve diğer ŞiOO üyelerinden fazladır. Düşük ve orta teknolojili ürünlerde de Rusya, Kazakistan ve Kırgızistan, karşılaştırmalı üstünlüğe sahip oldukları ürün oranlarının düşük olması nedeniyle Türkiye ile diğer Şı̈Ö üyelerinden ayrılmaktadır. Düşük teknolojili ürünlerde rekabeti belirleyen daha çok işçi maliyetleri olduğundan, Türkiye'nin özellikle Çin ve Hindistan'a karşı bu sinıflandırmaya sahip olan ürünlerde karşılaştırmalı üstünlügünü korumaya çalışmak yerine, etkin araştırmageliştirme ve yenilik politikalarıyla üretim modelini orta ve ileri teknolojili mamullere doğru kaydırması gerekmektedir. 